Article

\title{
Exploitation of Large Archives of ERS and ENVISAT C-Band SAR Data to Characterize Ground Deformations
}

\author{
Chiara Del Ventisette ${ }^{1}{ }^{*}$, Andrea Ciampalini ${ }^{1}$, Michele Manunta ${ }^{2}$, Fabiana Calò ${ }^{2}$, \\ Luca Paglia $^{2}$, Francesca Ardizzone ${ }^{3}$, Alessandro Cesare Mondini ${ }^{3}$, Paola Reichenbach ${ }^{3}$, \\ Rosa Maria Mateos ${ }^{4}$, Silvia Bianchini ${ }^{1}$, Immaculada Garcia ${ }^{5}$, Balázs Füsi ${ }^{6}$, \\ Zsuzsa Villő Deák ${ }^{6}$, Károly Rádi ${ }^{6}$, Marek Graniczny ${ }^{7}$, Zbigniew Kowalski ${ }^{7}$, \\ Anna Piatkowska ${ }^{7}$, Maria Przylucka ${ }^{7}$, Hugo Retzo $^{8}$, Tazio Strozzi ${ }^{9}$, Davide Colombo ${ }^{10}$, \\ Oscar Mora ${ }^{11}$, Francisco Sánchez ${ }^{11}$, Gerardo Herrera ${ }^{12}$, Sandro Moretti ${ }^{1}$, \\ Nicola Casagli ${ }^{1}$ and Fausto Guzzetti ${ }^{3}$
}

1 Earth Sciences Department, University of Firenze, Via La Pira, 4, I-50121 Firenze, Italy; E-Mails: andrea.ciampalini@unifi.it (A.C.); silvia.bianchini@unifi.it (S.B.); sandro.moretti@unifi.it (S.M.); nicola.casagli@unifi.it (N.C.)

2 Istituto per il Rilevamento Elettromagnetico dell'Ambiente (IREA), National Research Council (CNR), Via Diocleziano 328, I-80124 Napoli, Italy; E-Mails: manunta.m@irea.cnr.it (M.M.); calo.f@irea.cnr.it (F.C.); paglia.1@irea.cnr.it (L.P.)

3 Istituto di Ricerca per la Protezione Idrogeologica (IRPI), National Research Council (CNR), Via Madonna Alta 126, I-06128 Perugia, Italy; E-Mails: francesca.ardizzone@irpi.cnr.it (F.A.); alessandro.mondini@irpi.cnr.it (A.C.M.); paola.reichenbach@irpi.cnr.it (P.R.); fausto.guzzetti@irpi.cnr.it (F.G.)

4 Geological and Mining Institute of Spain, Urb. Alcázar del Genil, 4. Edificio Zulema bajos, E-18006 Granada, Spain; E-Mail: rm.mateos@igme.es

5 Geological and Mining Institute of Spain, Avda. Ciudad Querétaro s/n., E-07007 Palma de Mallorca, Spain; E-Mail: inmaculada.garcia@igme.es

6 Magyar Földtani és Geofizikai Intézet (MFGI), XIV. ker. Kolumbusz u. 17-23, 1145 Budapest, Hungary; E-Mails: fusi.balazs@mfgi.hu (B.F.); deak.villo@mfgi.hu (Z.V.D.); radi.karoly@mfgi.hu (K.R.)

7 Polish Geological Institute, National Research Institute, 00975 Warsaw, Poland; E-Mails: marek.graniczny@ pgi.gov.pl (M.G.); zbigniew.kowalski@ pgi.gov.pl (Z.K.); anna.piatkowska@pgi.gov.pl (A.P.); maria.przylucka@pgi.gov.pl (M.P.)

Federal Office for the Environment (FOEN), CH-3003 Berna, Switerland;

E-Mail: Hugo.Raetzo@bafu.admin.ch

GAMMA Remote Sensing Research and Consulting AG, Worbstr. 225, CH-3073 Gümligen;

Switzerland; E-Mail: strozzi@gamma-rs.ch

10 TRE s.r.l., TeleRilevamentoEuropa, Ripa di Porta Ticinense 79, I-20143 Milan, Italy;

E-Mail: davide.colombo@ treuropa.com 
11 Altamira Information, C/. Còrsega 381-387; E-08037 Barcelona, Spain;

E-Mails: geraint.cooksley@ altamira-information.com (O.S.);

francisco.sanchez@altamira-information.com (F.S.)

12 Geohazards InSAR Laboratory (InSARlab), Geological Survey of Spain (IGME), C/. Alenza 1; E-28003 Madrid, Spain; E-Mail: g.herrera@igme.es

* Author to whom correspondence should be addressed; E-Mail: chiara.delventisette@ unifi.it; Tel.: +39-55-205-5302; Fax: +39-55-205-5317.

Received: 8 June 2013; in revised form: 31 July 2013 / Accepted: 1 August 2013 /

Published: 8 August 2013

\begin{abstract}
In the last few years, several advances have been made in the use of radar images to detect, map and monitor ground deformations. DInSAR (Differential Synthetic Aperture Radar Interferometry) and A-DInSAR/PSI (Advanced DInSAR/Persistent Scatterers Interferometry) technologies have been successfully applied in the study of deformation phenomena induced by, for example, active tectonics, volcanic activity, ground water exploitation, mining, and landslides, both at local and regional scales. In this paper, the existing European Space Agency (ESA) archives (acquired as part of the FP7-DORIS project), which were collected by the ERS-1/2 and ENVISAT satellites operating in the microwave C-band, were analyzed and exploited to understand the dynamics of landslide and subsidence phenomena. In particular, this paper presents the results obtained as part of the FP7-DORIS project to demonstrate that the full exploitation of very long deformation time series (more than 15 years) can play a key role in understanding the dynamics of natural and human-induced hazards.
\end{abstract}

Keywords: landslides; subsidence; SAR Interferometry; deformation time series; ground deformation dynamics

\title{
1. Introduction
}

Ground deformations, including mass movements and land subsidence, result from a variety of natural and human causes and triggers. These phenomena are frequent and widespread and cause extensive economic damage to private property and public assets. In Europe and throughout the world, the large number of areas affected by ground deformations, the frequency and extent of the triggering events, and the extent of the impacts and the magnitude of the damage require a multi-scale, systematic approach. Often, the complexity of the problem is such that it cannot be tackled (and solved) on an individual, site-specific level or using a single technique or methodology; rather, the problem has to be approached by the integration of data taken at different scales and the collaborative efforts of researchers with multiple types of expertise. The multiple satellite sensors now available can be 
effectively exploited in combination with traditional methods and tools to detect, map, monitor and forecast ground deformations over large areas and with the required accuracy. In recent years, largely as a result of research initiatives funded by the European Commission (EC), the European Space Agency (ESA), and individual national agencies, significant progress has been made in the innovative exploitation of Earth Observation (EO) data and technology to detect, map and monitor ground deformations. In such a context Differential Synthetic Aperture Radar (SAR) Interferometry (DInSAR) has emerged as an effective microwave remote sensing technique for detecting and mapping surface displacements over large temporal and spatial scales, with centimeter to millimeter accuracy [1]. In particular, in the last few years, several Advanced DInSAR (A-DInSAR) techniques have been developed to follow the temporal evolution of deformation phenomena via the generation of displacement time series. Such advanced techniques have been successfully applied to the study of deformation phenomena induced by active tectonics, volcanic activity, ground water exploitation, mining, and landslides at both local and regional scales [2-12].

This paper presents the results obtained by the exploitation of large archives of satellite C-band SAR data under the auspices of DORIS (Ground Deformation Risk Scenarios: an advanced Assessment Service), an integrated project within the Seventh Framework Program of the European Commission. DORIS is an advanced downstream service project that integrates traditional and innovative EO and non-EO (ground based) data and technologies to improve the understanding of complex deformation phenomena as landslides and subsidence. To do this, ESA SAR data archives, collected by the ERS-1/2 and ENVISAT satellites operating in the microwave C-band during almost two decades (1992-2010), were analyzed and exploited on different environmental settings and deformation phenomena using various A-DInSAR techniques. The temporal continuity and geometric compatibility among ERS-1/2 and ENVISAT data represent a unique opportunity to develop very long deformation time series suitable to perform back-analysis of the investigated deformation phenomena. This approach provides valuable information for understanding the behavior of slow and very-slow deformation phenomena over long time intervals, thus playing a key role in risk mitigation strategies and civil protection activities. To this aim, the test sites (Figure 1) investigated within the DORIS Project were selected to include different types of ground deformations (Table 1) and to represent a wide range of physiographic and environmental settings.

Figure 1. Map showing DORIS test sites. The phenomena presented in the paper are listed in Table 1 (from GoogleEarth).

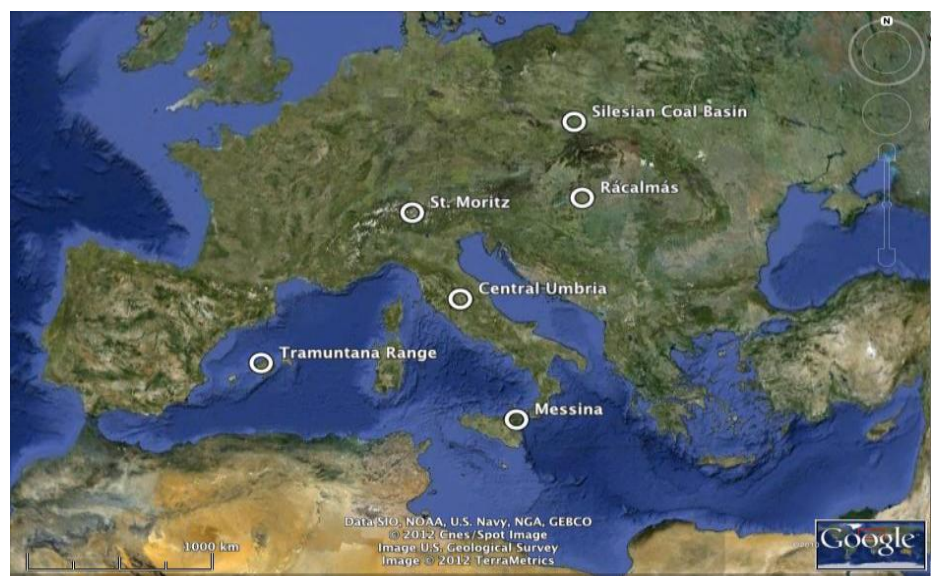


Table 1. Ground deformation phenomena identified in the selected test area.

\begin{tabular}{ccc}
\hline Country & Area & Phenomena \\
\hline Italy & Central Umbria & Subsidence and Landslide (Ivancich) \\
& Messina Province (Sicily) & Landslide (San Fratello) \\
Hungary & Danube Riverbank & Landslide (Rácalmás) \\
Poland & Silesian Coal Basin & Subsidence \\
Spain & Tramuntana Range (Mallorca) & Landslide \\
Switzerland & St. Moritz & Landslide \\
\hline
\end{tabular}

In particular, in this paper we focus on the analysis of ground subsidence and landslides, characterized by different triggers and mechanisms and affecting different geological settings. The land subsidence occurring in the Umbria region (Italy) is caused by water pumping, while in the Silesian Coal Basin (Poland) subsidence is mainly induced by mining activities. As regards landslides, the test sites chosen for our studies are characterized by different typology, dynamics and geological background. Through the comparison of the results achieved by analyzing such different case studies, the aim of this paper is to point out the relevance of the A-DInSAR techniques, regardless of the employed core algorithms, to understand ground deformation dynamics and at the same time to synthesize generally valid statements about the characteristics of this surveying remote sensing technique.

\section{SAR Datasets, Processing Techniques and Product Accuracy}

DInSAR is a remote sensing technique that exploits the phase difference (i.e., the interferogram) between SAR data pairs acquired over the same area at different times, allowing production of deformation maps with centimeter to millimeter accuracy $[1,13,14]$. Since the 1990s, A-DInSAR techniques relying on multi-interferogram or multi-image algorithms to study slow ground deformation [15-28] have been developed to overcome some of the limitations (temporal and geometrical decorrelation, atmospheric artifact filtering) related to conventional DInSAR approaches based on the use of single interferograms. Among the A-DInSAR techniques used in the DORIS project are the following: (i) the SBAS (Small BAseline Subset) technique developed by the National Research Council (CNR-IREA) [21,22]; (ii) IPTA (Interferometric Point Target Analysis) by GAMMA Remote Sensing [17,18]; (iii) PSInSAR (Permanent Scatterers Interferometric SAR) by TeleRilevamento Europa (T.R.E.) [19,20], and the SPN (Stable Point Network) by Altamira Information [23,24]. Furthermore, to exploit SAR data captured by different radar systems acquired with the same illumination geometry, e.g., the ERS-1/2 and ENVISAT satellites, various approaches have been developed centered on (i) new algorithms for image processing [29,30] and (ii) enhanced post-processing approaches [31].

The applied A-DInSAR approaches are well-consolidated techniques and have been demonstrated to be effective tools for detecting and monitoring surface deformation phenomena with millimetric accuracy. The validation of products retrieved through A-DInSAR methods, applied to ERS-1/2 and ENVISAT datasets, has already been a matter of extensive discussion [24,27,29,32-35]. In particular according to extensive validation analyses based on high precision geodetic techniques, i.e., GPS and leveling measurements, it turns out that a realistic number for the standard deviation of the errors affecting DInSAR time series is within the range of 5-10 $\mathrm{mm}[29,36,37]$. Concerning the mean 
deformation velocity, the standard deviation is of about $1-2 \mathrm{~mm} / \mathrm{yr}$. It is worth pointing out that such analyses are based on the use of "standard" SAR datasets, composed by at least 30 images and covering wide regions. The estimated accuracies refer to mean values computed with respect to several geodetic benchmarks distributed over the whole investigated areas, and the better values have been retrieved for the measure targets nearest to the chosen reference point [36]. Moreover, it has also been demonstrated that in particular cases, i.e., urbanized or scarcely vegetated areas, characterized by high density of coherent points, better accuracy can be obtained [37].

To understand ground deformation dynamics of different phenomena in different environmental settings, large ERS and ENVISAT datasets (Table 2) spanning the time interval between 1992 and 2010 were collected and processed.

Table 2. C-Band satellite images available for each DORIS test site.

\begin{tabular}{|c|c|c|c|c|c|c|}
\hline & est Site & Satellite & Orhit & Start date & Fnd date & Image \# \\
\hline Country & Location & Satemite & OHDit & Stait uate & Emu uate & mage $f$ \\
\hline \multirow{8}{*}{ Italy } & \multirow{4}{*}{ Central Umbria } & \multirow{2}{*}{ ERS } & Ascending & 1995.06 .30 & 2006.11 .25 & 36 \\
\hline & & & Descending & 1992.04 .21 & 2010.11 .12 & 91 \\
\hline & & \multirow{2}{*}{ ENVISAT } & Ascending & 2002.11 .16 & 2010.09 .25 & 51 \\
\hline & & & Descending & 2003.10 .10 & 2010.09 .03 & 39 \\
\hline & \multirow{4}{*}{$\begin{array}{c}\text { Messina } \\
\text { Province (Sicily) }\end{array}$} & \multirow{2}{*}{ ERS } & Ascending & 1992.09 .11 & 2000.06 .05 & 34 \\
\hline & & & Descending & 1992.05.01 & 2001.01 .08 & 70 \\
\hline & & \multirow{2}{*}{ ENVISAT } & Ascending & 2003.01.22 & 2010.09.22 & 65 \\
\hline & & & Descending & 2003.07.07 & 2010.09 .13 & 49 \\
\hline \multirow{2}{*}{ Hungary } & \multirow{2}{*}{ Rácalmás } & ERS & Descending & 1992.11.24 & 2000.12 .01 & 56 \\
\hline & & ENVISAT & Descending & 2001.11.01 & 2010.09.10 & 35 \\
\hline \multirow{2}{*}{ Poland } & \multirow{2}{*}{ Silesian Coal Basin } & ERS & Descending & 1992.05 .17 & 2000.12 .20 & 70 \\
\hline & & ENVISAT & Descending & 2003.03 .05 & 2010.09 .29 & 31 \\
\hline \multirow{3}{*}{ Spain } & \multirow{3}{*}{$\begin{array}{l}\text { Tramuntana Range } \\
\text { (Mallorca) }\end{array}$} & ERS & Descending & 1992.06 .13 & 2000.11 .07 & 39 \\
\hline & & \multirow{2}{*}{ ENVISAT } & Descending & 2003.08 .19 & 2009.05.19 & 22 \\
\hline & & & Ascending & 2003.11.22 & 2010.04 .24 & 25 \\
\hline \multirow{4}{*}{ Switzerland } & \multirow{4}{*}{ St. Moritz } & \multirow{2}{*}{ ERS } & Ascending & 1992.05 .16 & 2000.10 .10 & 26 \\
\hline & & & Descending & 1992.06 .04 & 2000.10 .29 & 41 \\
\hline & & \multirow{2}{*}{ ENVISAT } & Ascending & 2002.10 .15 & 2010.09 .28 & 36 \\
\hline & & & Descending & 2004.05 .16 & 2010.10 .17 & 35 \\
\hline
\end{tabular}

\section{Application of A-DInSAR to Understanding Ground Deformation Dynamics}

\subsection{Central Umbria (Italy)}

Central Umbria (Italy) is affected by various types of ground deformation, and we focus on the deep-seated Ivancich landslide located in the Assisi municipality and a subsidence phenomenon that involves a portion of the Valle Umbra (Figure 2). Geomorphological, geotechnical, and topographical investigations revealed that the landslide is a very old slide involving a debris deposit covering the bedrock, which consists of a pelitic sandstone unit; more recent slides have developed within the old landslide deposit. The recent slope failures have caused damage to roads and private and public 
buildings, including the Assisi hospital [38]. The subsidence phenomenon affects the Valle Umbra, near the village of Cannara; this deformation is induced by the exploitation of nine wells extracting water from a deep confined aquifer [39, 40]).

Figure 2. (Top) Deformation velocity maps at low spatial resolution (pixel size $\approx 100 \mathrm{~m}$ by $100 \mathrm{~m}$ ) related to the Umbria region (central Italy), superimposed on an optical image. The purple star indicates the reference points used in the two Differential Synthetic Aperture Radar Interferometry (DInSAR) analyses; (Bottom) Displacement time series relevant to the area around Perugia affected by subsidence caused by aquifer exploitation (white circle). The black and red triangles in the two deformation time series plot refer to the ERS and ENVISAT acquisitions, respectively.
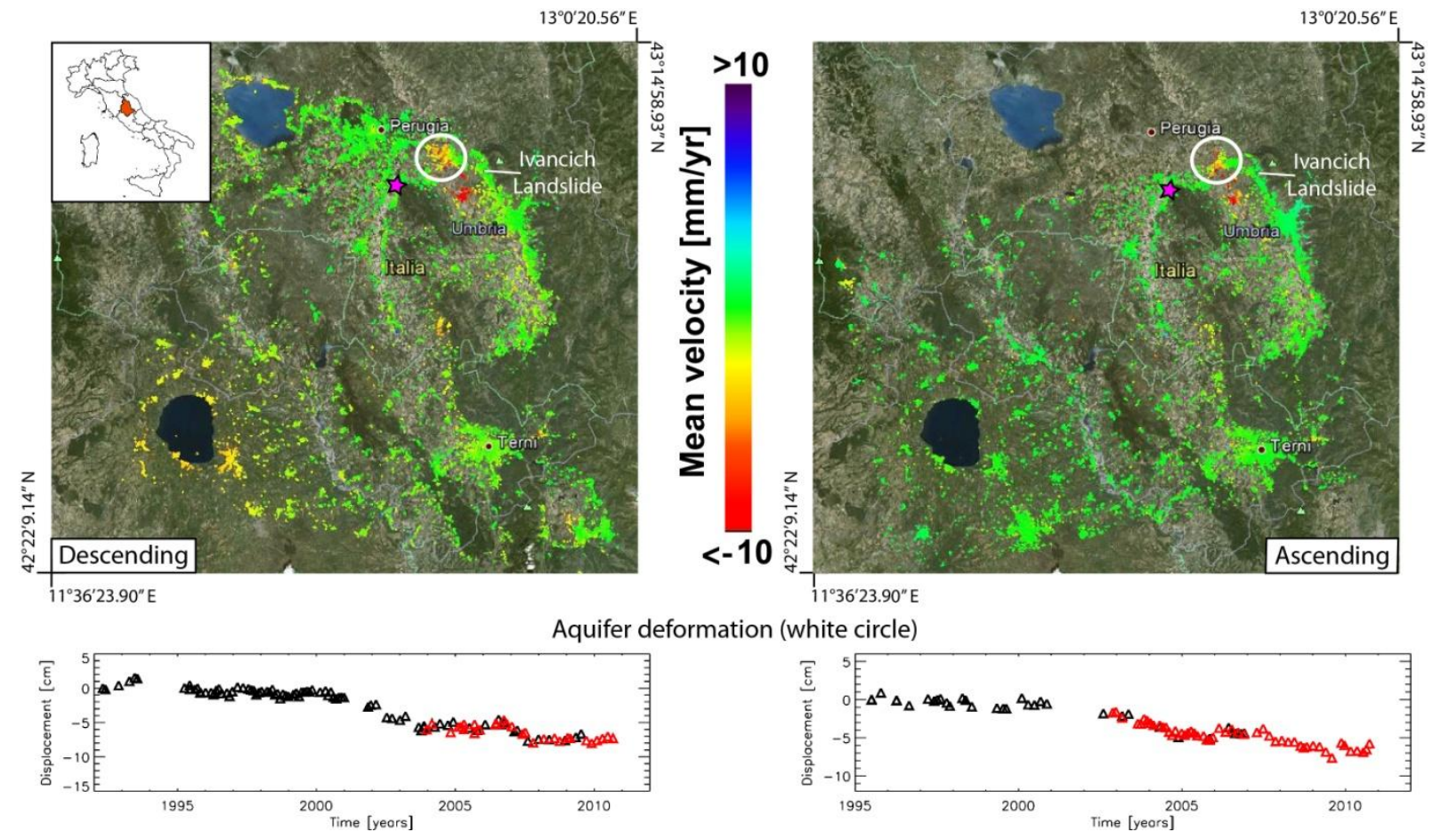

The multi-scale, multi-sensor SBAS technique [21,22,29] has been applied to investigate the regional and local deformation patterns affecting the study area (Figure 2).

As a result of the regional SBAS analysis, low-resolution deformation velocity maps and associated time series for both datasets (Table 2) have been produced, allowing detection of geologic displacement phenomena occurring within the entire investigated area. Surface displacements have been computed with respect to a stable reference point located south of Perugia (purple star in Figure 2). Analyses from both descending and ascending orbits show a widespread deformation pattern induced by aquifer exploitation in the Valle Umbra (Figure 2) since 1992, which has already been discussed by others [40]. However, the current analysis, which spans from 1992 to 2010 (Table 2), reveals an area between Assisi and Perugia (highlighted in Figure 2 with a white circle) exhibiting ground displacements that have occurred only after 2000 and not detected in previous studies [40].

To gain further insights into the behavior of localized phenomena, we carried out multi-sensor SBAS analysis at a full spatial resolution on the Ivancich landslide area. In Figure 3, the full resolution deformation velocity map and the time series associated with two measurement points located on the 
Ivancich landslide body are shown. Such local-scale SBAS analysis allowed detection of an active section of slope instability that shows a clear deformation trend during the observed time period (Figure 3).

Figure 3. Deformation velocity map at full spatial resolution (pixel size $\approx 20 \mathrm{~m}$ by $4 \mathrm{~m}$ ) related to the Assisi area (upper left) and an enlarged portion of the Ivancich landslide (upper right). Deformation time series (lower left) relevant to two differential synthetic aperture radar (SAR) points located within the active sector of the mass movement. Damage occurred in the landslide area (lower right). The black and red triangles in the two deformation time series plot refer to the ERS and ENVISAT acquisitions, respectively.
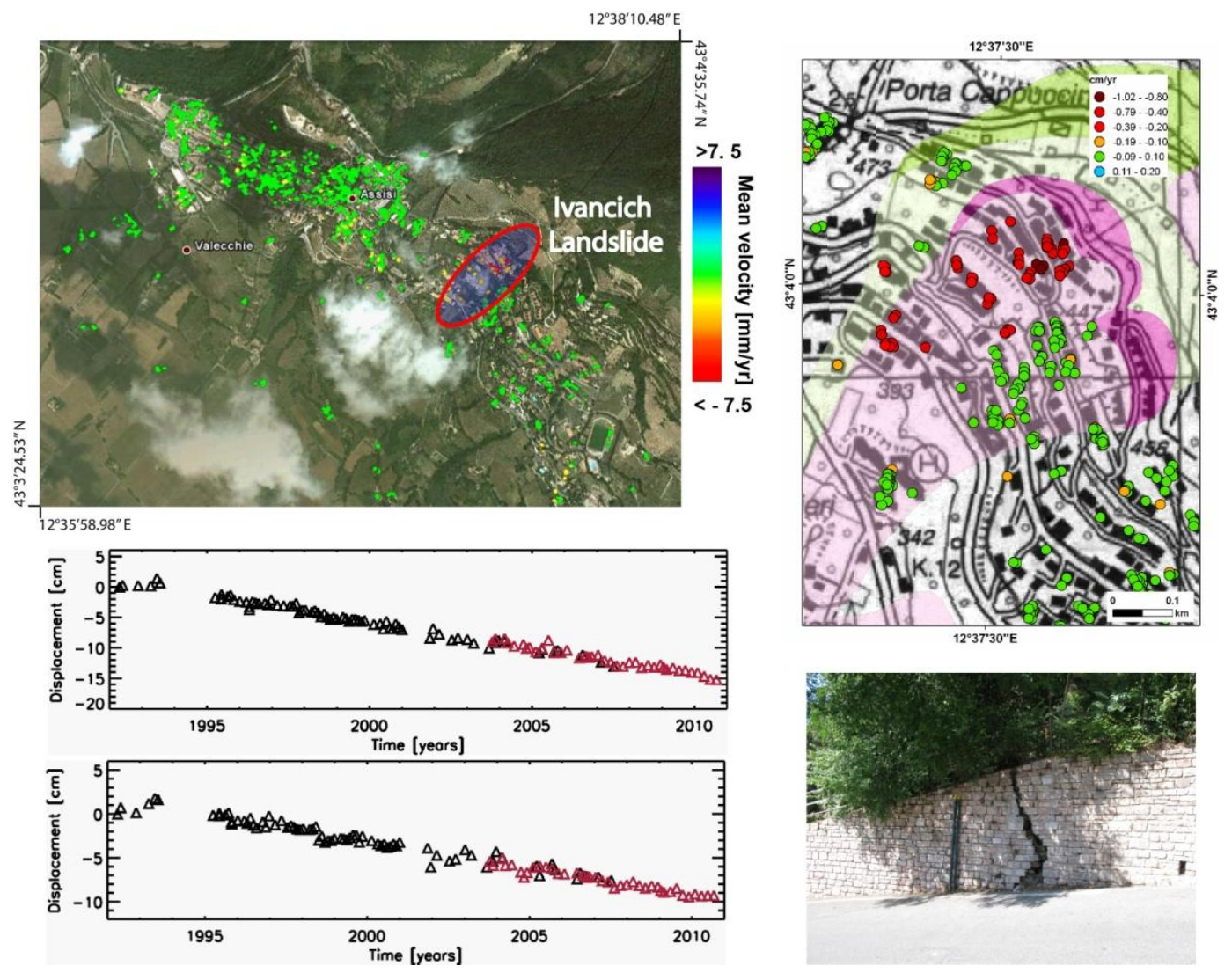

\subsection{Nebrodi, Messina Province (Italy)}

In the period from October 2009 to February 2010, the Nebrodi area (Messina Province) was highly affected by severe storms that triggered several landslides causing intense damage to structures and infrastructure with some casualties [41,42]. In the official landslide inventory maps (IFFI and PAI; both updated in 2004), several landslides are mapped in the San Fratello area (Figure 4). Two severe landslide events date back to 1754, when the town was almost completely destroyed, and to early 1922, when the village was evacuated and the inhabitants, who moved along the coast as ordered by a royal decree, founded the village of Acquedolci.

On 14 February 2010, a landslide developed on the east slope, affecting the central and the eastern portion of the town and, in particular, damaging the districts of San Benedetto, Riana and Stazzone. This landslide is a rotational slide mainly involving debris and causing considerable surface 
deformation. The landslide covers an area of approximately $0.93 \mathrm{~km}^{2}$, has a perimeter of $5.3 \mathrm{~km}$, and has a maximum length of approximately $1.9 \mathrm{~km}$ and a maximum width of approximately $950 \mathrm{~m}$. The area was affected by further mass movements in March 2011, when 12 people were evacuated.

Figure 4. Examples of Permanent Scatterers Interferometric SAR (PSInSAR) data available for the town of San Fratello. (a) ERS descending dataset (b) ENVISAT descending dataset, (c) ERS-ENVISAT stitched (merged) dataset. Zoom on the 1922 landslide crown: (d) ERS descending dataset; (e) ENVISAT descending dataset; (f) ERS-ENVISAT stitched (merged) dataset. The 1922 landslide crown is shown in orange; the 2010 landslide boundary (the landslide boundary corresponding to that shown on the map prepared by the Sicily Regional Civil Protection Department) is shown in red; (g) Example of ground deformation induced by the 2010 landslide.

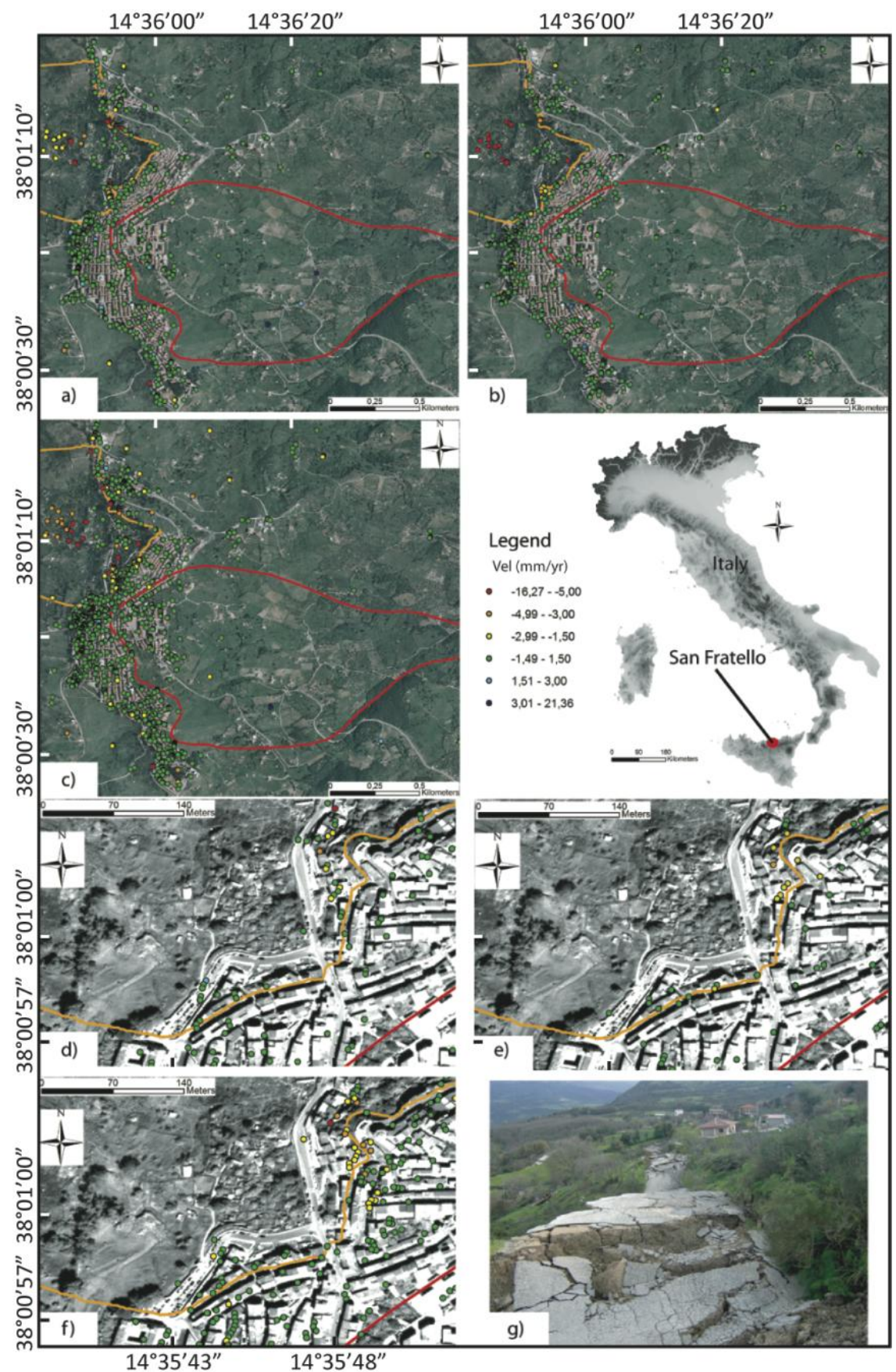


The available images (Table 2) have been processed by TRE using two different approaches: the first approach consisted of distinct processing of the ERS and ENVISAT images; the second consisted of joint processing of the ERS and ENVISAT images. Both approaches exploit the PSInSAR ${ }^{\mathrm{TM}}$ algorithm developed by [18]. The results of the processing are shown in Figure 4. The density of PSs is comparable among the three datasets (approximately $20 \mathrm{PS} / \mathrm{km}^{2}$ ). Due to the slope orientation, the descending (orbit) dataset was used to analyze the terrain affected by the 1922 landslide, and the ascending dataset was used to analyze the area affected by the 2010 landslide movements. In the period between 11 September 1992 and 5 June 2000 (ERS dataset), no significant deformation was observed in the 2010 landslide area, while on the upper part of the 1922 landslide, deformations reaching $8 \mathrm{~mm} / \mathrm{yr}$ were identified.

The ENVISAT data (covering the years 2003 to 2010) were used to identify unstable sectors in the 1922 landslide body (where the velocity reached $10.3 \mathrm{~mm} / \mathrm{yr}$ ) and in the 2010 landslide area. In the latter landslide area, between 2003 and 2010, some PSs show deformations greater than $10 \mathrm{~mm} / \mathrm{yr}$. The analysis of the time series in the 2010 landslide area indicates two periods with increasing deformation rates (Figure 5): one in 2005 and another between 2009 and 2010 (well recognizable in Stitched ERS-ENVISAT time series, Figure 5e-f).

Figure 5. Example of time series. (a,b) ERS; (c,d) ENVISAT and (e,f) stitched ERS-ENVISAT PS dataset.



If we consider the ERS-ENVISAT stitched data set, although these data contain a higher density of points in the landslide area compared to either single dataset, no PSs are shown in the zone of the 2010 landslide that shows high velocity, most likely due to coherence losses of the targets. Regarding the 
1922 landslide, no further information was obtained by the analysis of the two data sets. The analysis using combined ERS and ENVISAT data is useful when the strains are extremely slow and single datasets do not reveal deformations, for example outside of the 1922 landslide (Figure 4d-e). The merged processing obtained by combining the two datasets allowed identification of unstable PSs (Figure 4f).

\subsection{Rácalmás Landslide, Danube Riverbank (Hungary)}

In Hungary, the main instability problem is related to the erosion and collapse of loess material along the Danube River, on the eastern shore of Lake Balaton and along hilly areas. The Rácalmás landslide area $\left(513 \mathrm{~km}^{2}\right)$ is characterized by several landslides whose activity dates back to 1925 (Figure 6a). This landslide is located on the right bank of the Danube River and is part of the steep, high riverbank that forms the national border. During the last few years, due to a high precipitation rate, several landslides have reactivated, causing damage to houses and infrastructure.

Figure 6. (a) Schematic map of the spatial and temporal distribution of the landslide events in the Rácalmás area; the colored lines represent the date of the event (obtained from historical sources); (b) ERS and ENVISAT SPN analysis; (c) ENVISAT SPN analysis results from the Rácalmás test site; and (d) Schematic cross section of the Rácalmás landslide affecting the Danube riverbank. HLW denotes high water level.
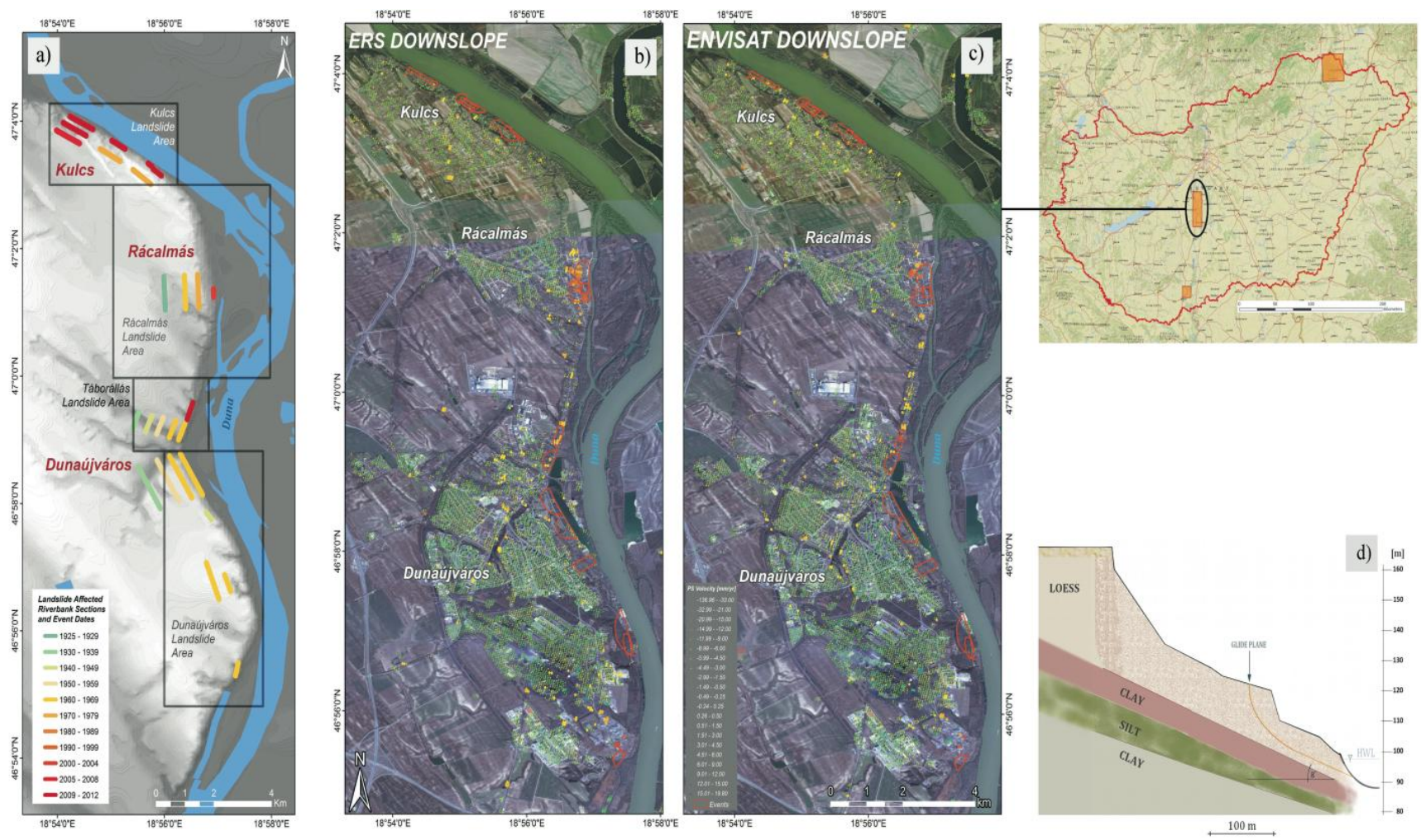

In the Rácalmás area, SPN analysis was carried out by Alatamira processing of the available images (Table 2). Separate processing was performed on the ERS-1/2 and ENVISAT data (Figure 6) to identify terrain deformation trends. 
The Rácalmás area is densely covered by PSs in both the ERS and ENVISAT datasets (Figure 7): the datasets derived from the ERS-1/2 and ENVISAT images processing consist of 24,634 PSs (48 PS/ $\mathrm{km}^{2}$ ) and 26,853 PSs (52.3 PS/ $\mathrm{km}^{2}$ ), respectively.

Figure 7. Maps showing ERS (a) and ENVISAT (b) data for the Rácalmás landslides area. ID numbers of the moving sectors; (c) Deformation Time Series; (d) statistical parameters of different sectors (e.g., A Figure 1 sector = RAC-ERS-C-01).

\section{Analysis with ERS \& ENVISAT satellite C-band SAR data of the Rácalmás landslide area}



Rácalmás landslide area with event boundaries, ERS \& ENVISAT PSs and moving sectors with different velocities

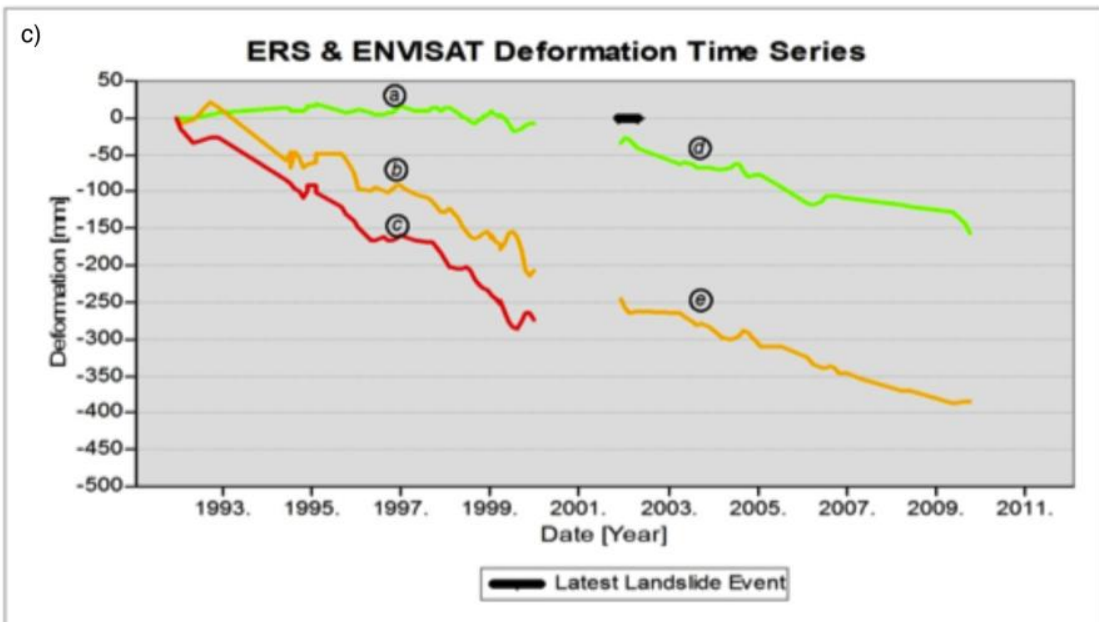

d)

ERS

\begin{tabular}{|c|c|c|c|c|c|}
\hline Ares id & Nos & $\begin{array}{c}\text { Max. } \\
\text { velocity }\end{array}$ & $\begin{array}{l}\text { Min. } \\
\text { Velioay }\end{array}$ & $\begin{array}{l}\text { Avereach } \\
\text { Veliody }\end{array}$ & $\begin{array}{l}\text { Standard } \\
\text { Deviatoon }\end{array}$ \\
\hline RACERSC-01 & 12 & $.19 x$ & 600 & .3 .85 & 1.2653 \\
\hline RACERSCQR & 5 & -0.61 & $.1,47$ & -1.1 & 0.360 \\
\hline AACERSCD & 3 & 422 & .0 .22 & .5 .28 & 0.942 \\
\hline AACERSCOA & 20 & 4 & .17 .25 & -108 & 5.3028 \\
\hline AACERSCOS & is & .10 .54 & .25 .58 & .18 .84 & 3.4916 \\
\hline PACERS- $\infty$ & 4 & .206 & 400 & .4 .36 & 0.817 \\
\hline RACERS-COI & 8 & .18 .94 & .33 .23 & .24 .12 & 4.3465 \\
\hline AACERSCO & 4 & .2 & $\$ 49$ & 468 & 2.5500 \\
\hline AACERS- $C 0$ & 3 & -861 & .10 .53 & -9.51 & a.7Bas \\
\hline AACERSC-10 & 7 & -0.7 & 4.15 & .244 & 1.2307 \\
\hline
\end{tabular}

Relative downslope displacement time series of individual ERS \& ENVISAT PSs

ENVISAT

\begin{tabular}{|c|c|c|c|c|c|}
\hline Nea iD & $\begin{array}{c}\text { PS } \\
\text { Number }\end{array}$ & $\underset{\text { Meliociy }}{\text { Max }}$ & $\underset{\text { Metiociy }}{\text { Mn }}$ & $\begin{array}{l}\text { Averace } \\
\text { Velocin }\end{array}$ & $\begin{array}{l}\text { Standerd } \\
\text { Deviation }\end{array}$ \\
\hline RACENMC-01 & 12 & -0.64 & -38 & -2.05 & 1.171 \\
\hline RACENMCER & 6 & 0.1 & .14 .45 & -7.04 & 4.8662 \\
\hline RACENM- 03 & 1 & .2 .94 & .2 .94 & .2 .94 & 0 \\
\hline RACENMCOA & 14 & 5.8 & .25 .72 & -14.78 & 8.362 \\
\hline RACENMCO6 & 1 & .19 .43 & $\cdot 19.13$ & - 19.13 & 0 \\
\hline RACENMCO & 1 & 34.37 & .34 .37 & .3437 & 0 \\
\hline RACENMCOP & 5 & -3.06 & -803 & -5.97 & 1.7041 \\
\hline RACENMCO & 9 & 0 & .7 .35 & 2.94 & 2217 \\
\hline RACENMC 00 & 5 & 200 & .748 & 4.00 & 1.7501 \\
\hline
\end{tabular}


Detailed local analyses of the Rácalmás failure were performed to better understand the landslide mechanism and to evaluate the performance of the ERS and ENVISAT C-band SPN technique when applied to large data archives. Projection of the velocities and deformation time series was made for selected PSs on the slope to calculate downslope components (Figure 7; the circles represent the LOS velocity; the triangles represent Downslope velocity). The analysis of PS mean velocity and distribution combined with geomorphology, geology, known event boundaries, scarps and crack lines allowed detection of temporally and spatially differentiated movements and delineation of areas with similar velocities.

In the Rácalmás area, the last event occurred between autumn 2002 and spring 2003. Because ERS time series are available for the pre-event period and ENVISAT series are available for the post-event period, it was possible to observe various accelerations in already unstable portions of the failure. For instance in sector ERS-C-6 the velocity increased from $4 \mathrm{~mm} / \mathrm{yr}$ (Figure $7 \mathrm{a}$ ) to $-34 \mathrm{~mm} / \mathrm{yr}$ (Figure 7b).

After the 2002-2003 landslide event (red square in Figure 7a,b), no PSs were detected within the landslide area from the ENVISAT dataset and in the nearby moving areas there were processed (ERS-C-07: -21.12 mm/yr, no PSs in this sector in the ENVISAT processing).

Note that in the ERS dataset the velocity reaches $-21 \mathrm{~mm} / \mathrm{yr}$ in the boundaries of the landslide (C7 in Figure 7a). The absence of PSs in both C-band datasets is due to the high velocity of the landslide that cannot be detected with PSI analysis.

Velocity distribution was interpolated to classify the landslide based on the movement velocity. The highest downslope velocity values $(<-35 \mathrm{~mm} / \mathrm{yr}$; Figure 7$)$ show good correlation with the slope area affected by the recent landslide event. Although there are no other ground measurements (e.g., surveying) to validate the interpolated velocities in the portions that lack PSs, these portions can be considered to be moving at low velocities.

Part of the landslide with a single PS (e.g., PS C-06 in the ENVISAT dataset) can also be evaluated because the mean velocity of these points is in good agreement with the velocity values obtained in the surrounding areas. Before the major landslide event, significantly higher velocities were detected $(-20$ to $-35 \mathrm{~mm} / \mathrm{yr})$ in the failure area.

\subsection{Silesian Coal Basin (Poland)}

Coal has been mined in the Upper Silesian coal basin (USCB, Poland; Figure 8) since the 19th century. At present there are thirty active coal mines in the USCB (estimated coal exploitation of 70 million t/yr). In the study area, hazardous ground deformations are caused primarily by the extensive longwall mining operations, located mainly in the vicinities of the cities of Katowice, Zabrze and Ruda Slaska. The subsidence in Upper Silesia reaches typical velocities of a few centimeters per month, but there are many areas with subsidence of one centimeter per day. Exploitation of coal deposits in the USCB for more than 200 years has caused complex conditions of stress and deformation, which is the cause of dynamic phenomena manifested in the form of rock mass shock. Systematic seismic observations have been carried out for approximately 60 years. The Central Mining Institute maintains an inventory of "strong mining tremors" based on data sent by the Upper Silesian Regional Seismic Network (GRSS) and the Mining Seismological Network (KSS). 
Figure 8. (a) Main tectonic structures and structural-geological map of the Upper Silesian coal basin (USCB) area of DORIS. Shown in yellow are active mines; in orange, abandoned mines; (b) ERS interferogram superimposed on a map of active and abandoned mines. Interferogram fringes indicate fast subsidence, which appear in the active mining area; (c) PS points from ERS (top) and ENVISAT (below). Comparison of these two datasets shows a decrease in the subsidence rate in recent years; (d) Time series of selected PS points from ERS and ENVISAT datasets from the same area. Graphs illustrate differences between subsidence trends in earlier (ERS, top) and later (ENVISAT, below) datasets.

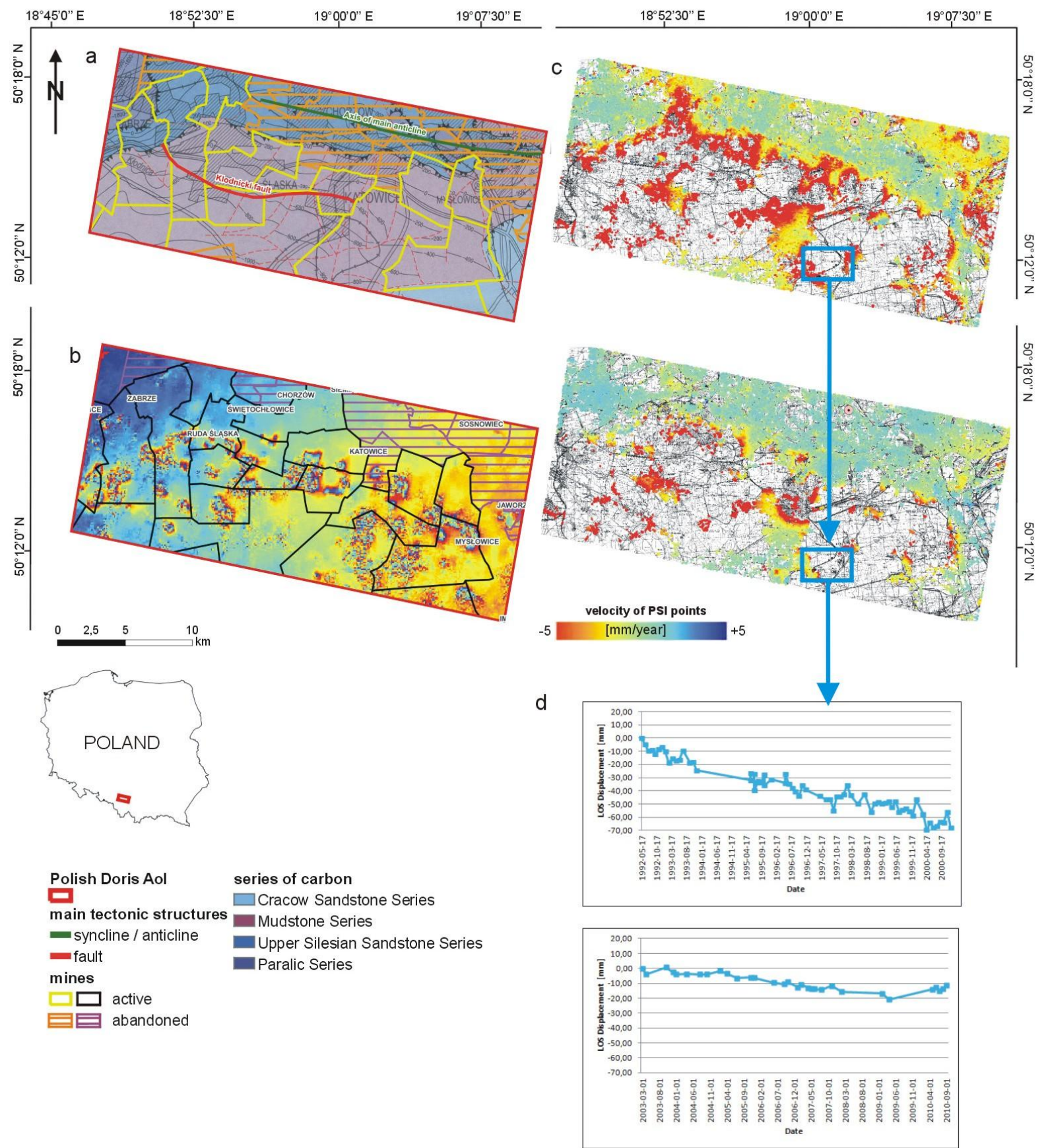

The PSInSAR processing was carried out to provide for highly accurate large-scale measurements of ground instabilities. PSI results were further analyzed and integrated with data related to mining activities, such as geological and mining maps. Through the integration of such auxiliary data and 
PSInSAR time series, the evolution of mining-induced movements can be analyzed and the effects of abandoned mining works on surface movement (i.e., ground subsidence, collapse or uplift due to mine water rise) can be assessed $[43,44]$. In addition, two differential interferograms from the same satellites were prepared to develop information in areas where, due to very high subsidence values, no PS points were detected (Figure 8 shows the interferogram from satellite ERS as an example of C-band interferograms). An ERS-ENVISAT stitched (merged) analysis of the Silesian coal basin area was not performed due to a significant nonlinear displacement that occurred in the temporal gap between the ERS and ENVISAT data.

The PSI datasets show average annual rates of movement ranging from -40.5 to $+7.41 \mathrm{~mm} / \mathrm{yr}$. The PS points with negative velocity values are located on the edge of the area prone to vertical ground subsidence caused by coal mining within the test site. The areas of great risk are not covered by PSs, mainly due to very high values of subsidence exceeding the capabilities of the PS analyses. In these areas, fringes are visible on both interferograms.

A correlation of the interferometric data with mining activity reveals that the PSs clearly illustrate the subsidence caused by coal mining in this area. However, there is no PS registered in areas strongly affected by coal mining, due to very high values of subsidence.

Based on an evaluation of the ENVISAT dataset, the subsidence is located in the central and southern parts of the area; the northern part, where there are no active mines, is mostly stable or shows minor uplift. This behavior could be related to the different hydrogeologic conditions. On closing the mines, hydrogeologic conditions change and groundwater levels rise, inducing a small uplift, especially around any fault zone. In addition, in the northeastern part of the USCB, the petrologic characteristics of the Carboniferous sandstones differ: these sandstones contain high percentages of argillaceous binder and common swelling minerals. As a result, the mechanical properties of the sandstones include low strength and high strain, and these rocks are sensitive to the influence of water. All results indicate that subsiding regions directly connected with mining activity have been characterized by decreasing rates of subsidence in recent years (Figures 8).

The PS spatial distribution in both datasets shows linear trends oriented WNW-ESE and W-E formed by changing values of ground motions. These trends correspond to the geologic boundaries of the productive Carboniferous sediments forming the coal basin (Upper Silesian Sandstone Series and Mudstone Series). These trends are also parallel to several regional structural features, including the Klodnicki fault. Therefore, these linear anomalies could be related to active faults and other geologic structures.

\subsection{Tramuntana Range (Mallorca)}

The island of Mallorca has a variety of geomorphologic domains, most prominently the Tramuntana Range $\left(1,100 \mathrm{~km}^{2}\right)$ in the northwestern part of the island (Figure 9). The steep topography of this mountain range, which is linked to its geologic complexity and Mediterranean climate, creates intense slope dynamics; most of the slope movements recorded on Mallorca occur after periods of short but intense or continuous rainfall [45].

During the period from 2008 to 2010, Mallorca experienced one of the coldest and rainiest winters in living memory, with accumulated rainfall twice the average recorded value. This period also 
witnessed the highest rates of intense rainfall (up to $296 \mathrm{~mm} /$ day) since instrumental recordkeeping began (1944). These rainy episodes also coincided with cold periods lasting several days with average temperatures approximately $0{ }^{\circ} \mathrm{C}$ and minima as low as $-6.8{ }^{\circ} \mathrm{C}$, which are anomalous values in the mild Mediterranean climate. One result was that 34 mass movements were triggered, distributed along the Tramuntana Range [46]. Fortunately, there were no deaths, but there were numerous cases of damage to dwellings, holiday apartment blocks, barns and power stations, and especially to the road network in the range; in particular, there were numerous blockages on the Ma-10 road, which caused significant economic losses in the various tourist resorts. The results of Fornalutx Landslide monitoring, using ERS-1/2 and ENVISAT data stacks from descending orbits (Table 2), is presented (Figure 9), showing a long time series obtained by joining the ERS-1/2 and ENVISAT deformation data.

Figure 9. ERS-ENVISAT PS (descending orbit) mean velocity and displacement time series in the Fornalutx landslide spanning the time interval between 1992 and 2009.

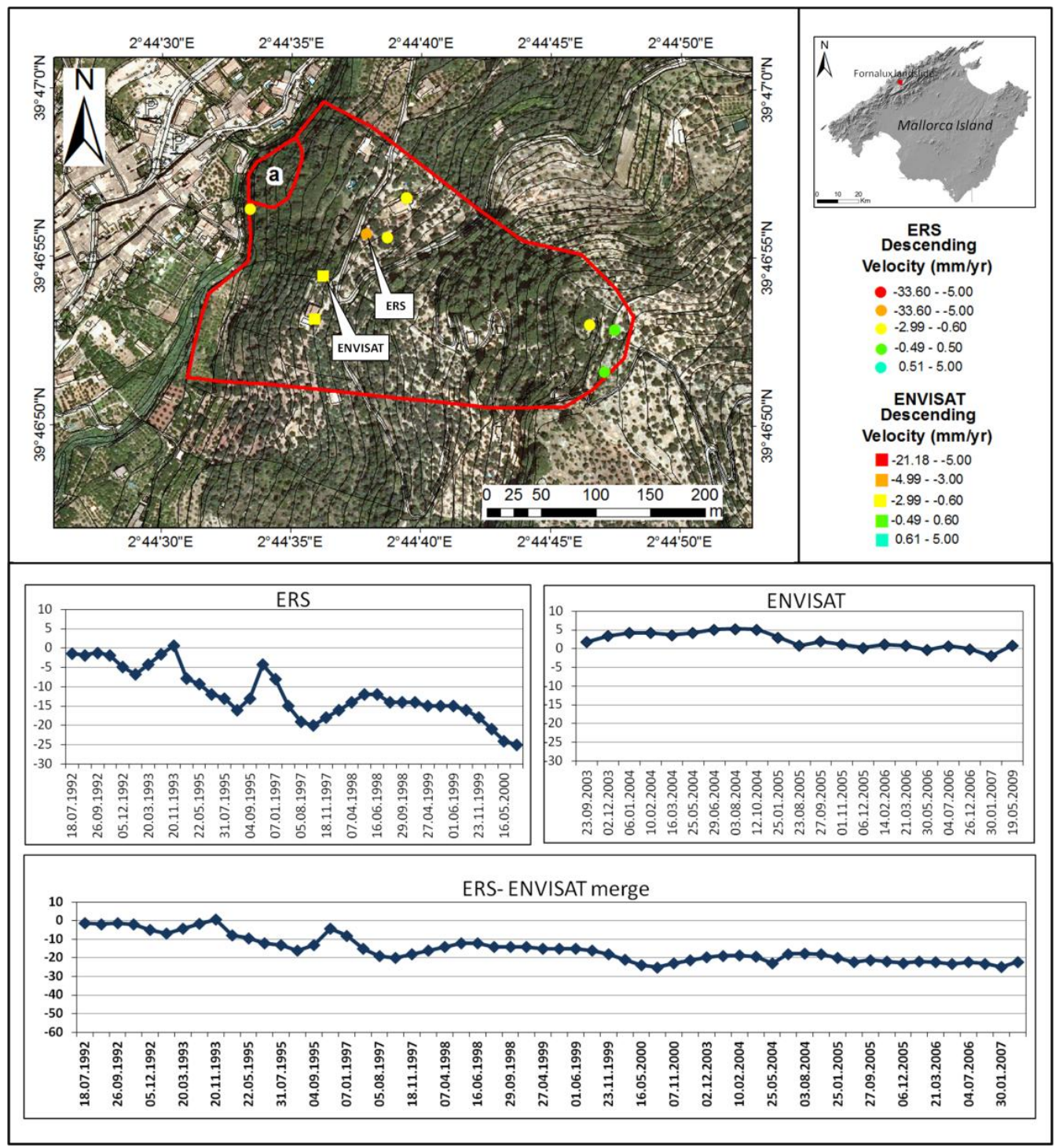

The Fornalutx landslide occurred in 1954; further local movement of the slope occurred in 1974 and 2002 after intense and continuous rainfall events. During the 2002 movement, only a small area of the 
toe of the slope rapidly mobilized immediately after rainfall events, causing a shallow debris flow (landslide (a) in Figure 9 [47]).

The ERS and ENVISAT medium-resolution data revealed few radar scatterers on the ground, thus providing a low PS density in the study area. Nevertheless, even few radar targets can be significant when additional data is available. In the Fornalutx site, in situ measurements and geomorphological field surveys indicate that the area is extensively affected by extremely slow landslide phenomena. In particular, according to the geomorphological, geotechnical and geophysical surveys, the lower part of the landslide motion shown in Figure 9 is identified as the area characterized by the highest potential instability due to the erosive action of the torrent at the toe; on the other hand, the central part of the landslide and the head scar did not register any movement according to the inclinometer readings performed between April and December 2006.

Measured displacements from ERS and ENVISAT data and related time series allow us to measure up to $25 \mathrm{~mm}$ of cumulative displacement until 2007 at the bottom part of the moving mass (Figure 9). This progressive displacement is not attributed to rainfall induced accelerations of the moving mass but rather to the natural (almost latent) dynamics of the landslide. As long as the mass does not accelerate, this magnitude of displacement is not expected to cause significant damage.

\subsection{St. Moritz (Switzerland)}

The famous destination of St. Moritz, in the Canton of Grison, lies high in the Bernina area of the Swiss Alps. Some peaks of 4,000 m a.s.l. surround the Engadine Valley, which holds Lake St. Moritz and Lake Silvaplana. Landslides, rock falls and frost heave are widespread; however, there is a lack of actual management in terms of spatial monitoring of ground movements. Due to climate change, these hazards should be integrated into an inventory to aid in hazard assessment and planning.

ERS and ENVISAT data were processed separately by Gamma Remote Sensing using the IPTA algorithm (Figure 10). Only summer images acquired between May and October were considered because of the snow cover present in other months.

The area of major interest is located north of the city of St. Moritz, where the density of points is sufficiently high to clearly discriminate between stable and moving areas. The SAR images from the ascending orbit show a slight increase in the rate of movement between the time interval of the ERS data $(\approx 6 \mathrm{~mm} / \mathrm{yr})$ and that of the ENVISAT data $(\approx 10 \mathrm{~mm} / \mathrm{yr})$.

The corresponding time series show a highly linear trend until 2008 and a slight change in activity thereafter (Figure 11). The line-of-sight displacement rates obtained from both ERS and ENVISAT data collected during the descending orbit are on the order of +2 to $+3 \mathrm{~mm} / \mathrm{yr}$.

The Envisat data was plotted considering a linear trend of deformation during the time not covered by images. Results from the PSI processing of the C-band ERS-1/2 and ENVISAT ASAR data show only the slowest moving part of the landslide, where rates of movement are below a couple of $\mathrm{cm} / \mathrm{yr}$. The area located in the middle of the St. Moritz landslide, with movement rates larger than these values, appear to lack information, similar to vegetated regions and slopes affected by layover and shadow. 
Figure 10. LOS deformation rates for St. Moritz: IPTA processing of SAR data from the ascending (a,b) and descending (c,d) orbit, from ERS (a,c) and ENVISAT (b,d).

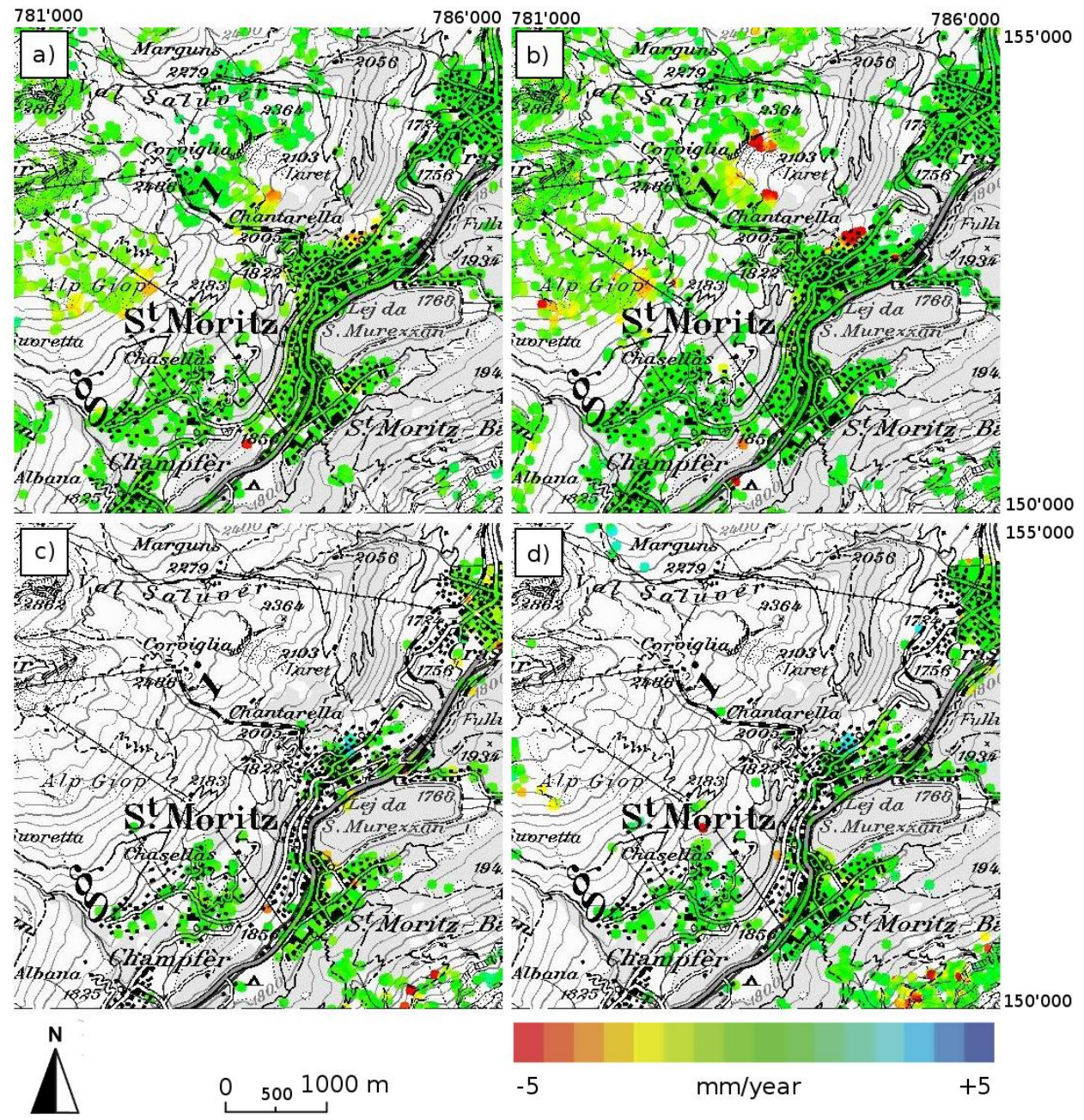

Figure 11. Displacement history for two point targets within the moving area north of St. Moritz for ERS and ENVISAT data from the ascending (a) and descending (b) orbit. Mean deformation rates are $-6.7 \mathrm{~mm} / \mathrm{yr}(+2.4 \mathrm{~mm} / \mathrm{yr})$ using ERS data and $-9.7 \mathrm{~mm} / \mathrm{yr}$ (+2.8 mm/yr) using ENVISAT data; pass direction is ascending, shown without brackets. and (descending), shown in brackets. The line represents the ERS mean deformation, and the ENVISAT time series was adjusted to that value.



\section{Discussion}

The presented results are focused on the application of C-band SAR data to obtain very long time series to understand ground deformation (subsidence and landslides) dynamics.

Concerning the ground subsidence the presented analyses are focused on A-DInSAR results achieved in test sites characterized by different triggered mechanisms (groundwater withdrawal in Umbria and mining in Poland) and different displacement rates (from $6 \mathrm{~mm} / \mathrm{yr}$ in Umbria to $-40 \mathrm{~mm} / \mathrm{yr}$ in Poland). In particular, the Umbria test site is affected by significant non-linear deformation signals and the presented analysis, performed through the use of very long time series, detected an area, located between Assisi and Perugia, affected by subsidence only after 2000. This finding highlights the effectiveness of the C-band multi-sensor SBAS approach in investigating the long-term behavior of deformation phenomena and in revealing a temporal evolution that significantly deviates from a linear trend. In the Poland area, where fast movement is detected with strong non-linear behavior, the understanding of the subsidence dynamics cannot benefit from the exploitation of very long time series; indeed in this case, a PSI analysis based on very high resolution $\mathrm{X}$-band SAR data characterized by an interferometric revisit time of a few days (e.g., Cosmo-SkyMed) would allow the retrieval of more detailed information useful to correlate the land behavior with the mining activities (both active and abandoned mines).

The reconstruction of very long time series is certainly far more beneficial to landslide detection and monitoring. In particular, it is possible to produce high resolution deformation maps allowing analysis in detail of slope instabilities, detecting the most active sectors, as in the case of the Ivancich mass movement, and in identifying incipient slidings, as for the Rácalmás landslide. Furthermore, in the San Fratello test site, the very long time series obtained combining ERS and ENVISAT datasets allowed the identification of unstable PSs in areas characterized by a low deformation rate thus improving the available information suitable to be exploited for the comprehension of the investigated phenomenon. In other cases, such as in Mallorca, this approach can assist, when additional data are available (i.e., in situ measurements and geomorphological field surveys), in understanding extremely slow landslide dynamics and in determining the highest potential instability sectors.

Furthermore, outcomes from such long-term analyses could play a key role in assessing the effectiveness of remedial works and defining risk mitigation strategies. The many examples presented in this work demonstrate that the A-DInSAR techniques can be applied in a uniform framework to various case studies, permitting the development of distinct interpretation strategies. Within the DORIS project efforts on the interpretation side are mainly focused on the direct transformation of the motion rates from the satellite line-of-sight direction into the direction of parallel slope as well as on the exploitation of DInSAR results for generating thematic maps and user-oriented products useful to further geo-hazard analyses.

\section{Conclusions}

In this paper six examples on the application of A-DInSAR (Advanced Differential Synthetic Aperture Radar Interferometry) products for the detection, mapping and monitoring ground deformation phenomena were presented. The results were obtained as part of the DORIS (Ground 
Deformation Risk Scenarios: an advanced Assessment Service) project, an integrated Seventh Framework Program project of the European Commission. In particular, ESA SAR data archives collected by the ERS-1/2 and ENVISAT satellites during the 1992-2010 time interval were processed by exploiting different A-DInSAR techniques, in order to provide very long deformation time series, benefiting from the temporal continuity and the geometric compatibility between ERS-1/2 and ENVISAT sensors.

The obtained results suggest the following main conclusion:

(1) A-DInSAR techniques, regardless of the employed core algorithms, represent effective tools for remotely measuring and investigating ground deformation scenarios, characterized by different mechanism, dynamics and geological/environmental settings;

(2) A-DInSAR techniques, thanks to their capability of analysis at different spatial scales, i.e., from regional to local, have been demonstrated to be suitable for exploring large land areas and identifying high risk zones that may further benefit from deeper analyses;

(3) Very long DInSAR deformation time series play a fundamental role for investigating the dynamics of landslides and subsidence, including those phenomena characterized by non-linear displacement trends.

\section{Acknowledgments}

The research leading to these results received funding from the European Union Seventh Framework Program (FP7/2007-2013) under grant agreement No. 242212. The anonymous reviewers are thanked for their critical review and for constructive comments that helped to improve the manuscript.

\section{Conflict of Interest}

The authors declare no conflict of interest.

\section{References}

1. Gabriel, A.K.; Goldstein, R.M.; Zebker, H.A. Mapping small elevation changes over large areas: Differential radar interferometry. J. Geophys. Res. 1989, 94, 9183-9191.

2. Colesanti, C.; Wasoswki, J. Investigating landslides with satellite synthetic aperture radar (SAR) interferometry. Eng. Geol. 2006, 88, 173-199.

3. Meisina, C.; Zucca, F.; Notti, D.; Colombo, A.; Cucchi, A.; Savio, G.; Giannico, C.; Bianchi, M. Geological interpretation of PSInSAR Data at regional scale. Sensor 2008, 8, 7469-7492.

4. Herrera, G.; García-Davalillo, J.C.; Mulas, J.; Cooksley, G.; Monserrat, O.; Pancioli, V. Mapping and monitoring geomorphological processes in mountainous areas using PSI data: Central Pyrenees case study. Nat. Hazards Earth Syst. Sci. 2009, 9, 1587-1598.

5. Cigna, F.; Del Ventisette, C.; Liguori, V.; Casagli, N. InSAR Time-Series Analysis for Management and Mitigation of Geological Risk in Urban Area. In Proceedings of the 2010 IEEE International Geoscience and Remote Sensing Symposium (IGARSS), Honolulu, HI, USA, 25-30 July 2010; pp. 1924-1927. 
6. Cigna, F.; Del Ventisette, C.; Liguori, V.; Casagli, N. Advanced radar-interpretation of InSAR time series for mapping and characterization of geological processes. Nat. Hazard Earth Syst. Sci. 2011, 11, 865-881.

7. Bonforte, A.; Guglielmino, F.; Coltelli, M.; Ferretti, A.; Puglisi, G. Structural assessment of Mount Etna volcano from Permanent Scatterers analysis. Geochem. Geophys. Geosyst. 2011, 12, Q02002.

8. Crosetto, M.; Monserrat, O.; Cuevas, M.; Crippa, B. Spaceborne Differential SAR Interferometry: Data Analysis Tools for Deformation Measurement. Remote Sens. 2011, 3, 305-318.

9. Bianchini, S.; Cigna, F.; Del Ventisette, C.; Moretti, S.; Casagli, N. Detecting and Monitoring Landslide Phenomena with TerraSAR-X Persistent Scatterers Data: The Gimigliano Case Study in Calabria Region (Italy). In Proceedings of the 2012 IEEE International Geoscience and Remote Sensing Symposium (IGARSS), Munich, Germany, 22-27 July 2012; pp. 982-985

10. Ciampalini, A.; Cigna, F.; Del Ventisette, C.; Moretti, S.; Liguori, V.; Casagli, N. Integrated geomorphological mapping in the north-western sector of Agrigento (Italy). J. Maps 2012, doi: 10.1080/17445647.2012.680775.

11. Cigna, F.; Del Ventisette, C.; Gigli, G.; Menna, F.; Agili, F.; Liguori, V.; Casagli, N. Ground instability in the old town of Agrigento (Italy) depicted by on-site investigations and Persistent Scatterers data. Nat. Hazards Earth Syst. Sci. 2012, 12, 3589-3603.

12. Herrera, G.; Gutierrez, F.; García-Davalillo, J.C.; Guerrero, J.; Notti, D.; Galve, J.P.; Fernández-Merodo, J.; Cooksley, G. Multi-sensor advanced DInSAR monitoring of very slow landslides: The Tena Valley case study (Central Spanish Pyrenees). Remote Sens. Environ. 2013, $128,31-43$

13. Massonnet, D.; Feigl, K.L. Radar interferometry and its application to changes in the Earth's surface. Rev. Geophys. 1998, 36, 441-500.

14. Rosen, P.A.; Hensley, S.; Joughin, I.R.; Li, F.K.; Madsen, S.N.; Rodriguez, E.; Goldstein, R.M. Synthetic aperture radar interferometry. Proc. IEEE 2000, 88, 333-382.

15. Mora, O.; Mallorqui, J.; Broquetas, A. Linear and non-linear terrain deformation maps from a reduced set of interferometric SAR images. IEEE Trans. Geosci. Remote Sens. 2003, 41, 2243-2253.

16. Tomás, R.; Marquez, Y.; Lopez-Sanchez, J.M.; Delgado, J.; Blanco, P.; Mallorquì, J.J.; Martìnez, M.; Herrera, G.; Mulas J. Mapping ground subsidence induced by aquifer overexploitation using advanced Differential SAR Interferometry: Vega Media of the Segura River (SE Spain) case study. Remote Sens. Environ. 2005, 98, 269-283.

17. Werner, C.; Wegmuller, U.; Strozzi, T.; Wiesmann, A. Interferometric Point Target Analysis for Deformation Mapping. In Proceedings of the 2003 IEEE International Geoscience and Remote Sensing Symposium, IGARSS’03, Toulouse, France, 21-25 July 2003; Volume 7, pp. 4362-4364.

18. Wegmuller, U.; Werner, C.; Strozzi, T.; Wiesmann, A. Monitoring Mining Induced Surface Deformations. In Proceedings of the 2004 IEEE International Geoscience and Remote Sensing Symposium, IGARSS '04, Anchorage, AK, USA, 20-24 September 2004; Volume 3, pp. 1933-1935.

19. Ferretti, A.; Prati, C.; Rocca F. Permanent scatterers in SAR interferometry. IEEE Trans. Geosci. Remote Sens. 2001, 39, 8-20.

20. Ferretti, A.; Fumagalli, A.; Novali, F.; Prati, C.; Rocca, F.; Rucci, A. A New Algorithm for Processing Interferometric Data-Stacks: SqueeSAR. IEEE Trans. Geosci. Remote Sens. 2011; 49 , 3460-3470. 
21. Berardino, P.; Fornaro, G.; Lanari, R.; Sansosti, E. A new algorithm for surface deformation monitoring based on Small Baseline Differential SAR interferograms. IEEE Trans. Geosci. Remote Sens. 2002, 40, 2375-2383.

22. Lanari, R.; Mora, O.; Manunta, M.; Mallorqui, J.; Berardino, P.; Sansosti, E. A small baseline approach for investigating deformations on full resolution differential SAR interferograms. IEEE Trans. Geosci. Remote Sens. 2004, 42, 1377-1386.

23. Arnaud, A.; Adam, N.; Hanssen, R.; Inglada, J.; Duro, J.; Closa, J.; Eineder, M. ASAR ERS Interferometric Phase Continuity. In Proceedings of the 2003 IEEE International Geoscience and Remote Sensing Symposium, IGARSS '03, Toulouse, France, 21-25 July 2003.

24. Herrera, G.; Fernández, J.A.; Tomás, R.; Cooksley, G.; Mulas J. Advanced interpretation of subsidence in Murcia (SE Spain) using A-DInSAR data-modelling and validation. Nat. Hazards Earth Syst. Sci. 2009, 9, 647-661.

25. Hooper, A.; Zebker, H.; Segall, P.; Kampes, B. A new method for measuring deformation on volcanoes and other natural terrains using InSAR persistent scatterers. Geophys. Res. Lett. 2004, 31, doi: 10.1029/2004GL021737.

26. Hooper, A.; Segall, P.; Zebker, H. Persistent scatterer InSAR for crustal deformation analysis, with application to Volcán Alcedo, Galàpagos. J. Geophys. Res. 2007, 112, doi: 10.1029/2006JB004763.

27. Costantini, M.; Rosen, P.A. A Generalized Phase Unwrapping Approach for Sparse Data. In Proceedings of the International Geoscience and Remote Sensing Symposium, Hamburg, Germany, 28 June-02 July 1999; pp. 267-269.

28. Costantini, M.; Iodice, A.; Pietranera, L. Temporal Analysis of Terrain Subsidence by Means of Sparse SAR Differential Interferometric Measurements. In Proceedings of the Conference on SAR Image Analysis, Modelling, and Techniques EOS/SPIE Symposium on Remote Sensing, Barcelona, Spain, 25 September 2000; pp. 12-18.

29. Bonano, M.; Manunta, M.; Marsella, M.; Lanari, R. Long term ERS/ENVISAT deformation time-series generation at full spatial resolution via the extended SBAS technique. Int. J. Remote Sens. 2012, 33, 4756-4783.

30. Pepe, A.; Sansosti, E.; Berardino, P.; Lanari, R. On the generation of ERS/ENVISAT DInSAR time-series via the SBAS technique. IEEE Geosci. Remote Sens. Lett. 2005, 2, 265-269.

31. Righini, G.; Pancioli, V.; Casagli, N. Updating landslide inventory maps using Persistent Scatterer Interferometry (PSI). Int. J. Remote Sens. 2012, 33, 2068-2096.

32. Small, D.; Holecz, F.; Nuesch, D. Combination of Ascending/Descending ERS-1 InSAR Data for Calibration and Validation. In Proceedings of the International Geoscience and Remote Sensing Symposium (IGARSS), Firenze, Italy, 10-14 July 1995; Volume 1, pp. 553-555.

33. Colesanti, C.; Ferretti, A.; Prati, C.; Rocca, F. Monitoring landslides and tectonic motions with the permanent scatterers technique. Eng. Geol. 2003, 68, 3-14.

34. Chen, J.; Wu, J.; Zhang, L.; Zou J.; Liu, G.; Zhang, R.; Yu, B. Deformation trend extraction based on multi-temporal InSAR in Shanghai. Remote Sens. 2013, 5, 1774-1786.

35. Tantianuparp, P.; Shi, X., Zhang, L.; Balz, T.; Liao, M. Characterization of landslide deformations in three gorges area using multiple InSAR data stacks. Remote Sens. 2013, 5, 2704-2719. 
36. Casu, F.; Manzo, M.; Lanari, R. A quantitative assessment of the SBAS algorithm performance for surface deformation retrieval from DInSAR data. Remote Sens. Environ. 2006, 102, 195-210.

37. Bonano, M.; Manunta, M.; Pepe, A.; Paglia, L.; Lanari, R. From previous c-band to new x-band SAR systems: Assessment of the DInSAR mapping improvement for deformation time-series retrieval in urban areas. IEEE Trans. Geosci. Remote Sens. 2013, 51, 1973-1984.

38. Felicioni, G.; Martini, E.; Ribaldi, C. Studio dei Centri Abitati Instabili in Umbria; Rubettino Publisher: Soveria Mannelli, Italy, 1994; p. 418.

39. Marchetti G.; Martinelli A. Gli Acquiferi Alluvionali dell'Umbria. In Le Acque Sotterranee in Umbria; Protagon: Perugia, Italy, 1991; pp. 145-167.

40. Guzzetti, F.; Manunta, M.; Ardizzone, F.; Pepe, A.; Cardinali, M.; Zeni, G.; Reichenbach, P.; Lanari, R. Analysis of ground deformation detected using the SBAS-DInSAR technique in Umbria, central Italy. Pure Appl. Geophys. 2009, 166, 1425-1459.

41. Ardizzone, F.; Basile, G.; Cardinali, M.; Casagli, N.; Del Conte, S.; Del Ventisette, C.; Fiorucci, F.; Gigli, G.; Garfagnoli, F.; Guzzetti, F.; et al. Landslide inventory map for the Briga and the Giampilieri catchments, NE Sicily, Italy. J. Maps 2012, doi: 10.1080/17445647.2012.694271.

42. Del Ventisette, C.; Garfagnoli, F.; Ciampalini, A.; Battistini, A.; Gigli, G.; Moretti, S.; Casagli, N. An integrated approach to the study of catastrophic debris-flows: Geological hazard and human influence. The case of Giampilieri (Sicily, Italy). Nat. Hazards Earth Syst. Sci. 2012, 12, 2907-2922.

43. Graniczny, M.; Piatkowska, A.; Pilecka, E. An application of the remote sensing technology to the high-energy seismic activity assessment, on the example of the Upper Silesian Coal Basin (USCB). Pol. Geological Inst. Special Pap. 2006, 20, 92-98.

44. Graniczny, M.; Czarnogorska, M.; Jureczka, J.; Kowalski, Z.; Piatkowska, A. Application of PS Interferometry for Identification of Geohazards-Case Study the Upper Silesian Coal Basin. The Abiotic Environment-Evaluation of Changes and Hazards-Case Studies; Abstracts and Field Trip Guide-Book; Centre of Excellence REA, Polish Geological Institute: Warsaw, Poland, 2006; pp. 16-17.

45. Mateos, R.M.; Azañón, J.M.; Morales, R.; López-Chicano, M. Regional prediction of landslides in the Tramuntana Range (Majorca) using probability análisis of intense rainfall. Zeitung für Geomorphol. 2007, 51, 287-306.

46. Mateos, R.M.; García-Moreno, I.; Azañón, J.M. Freeze-thaw cycles and rainfall as triggering factors of mass movements in a warm Mediterranean región: The case of the Tramuntana range (Mallorca, Spain). Landslides. 2011, doi: 10.1007/s10346-011-0290-8.

47. Mateos, R.M.; Bermejo, M.; Hijazo, T.; Rodríguez-Franco, J.A.; Ferrer, M.; de Vallejo, G.; García, I. Los deslizaminetos de la ladera de la margen izquierda del torrente de fiornalutx (Mallorca). Bol. Geol. Min. 2008, 118, 385-400.

(C) 2013 by the authors; licensee MDPI, Basel, Switzerland. This article is an open access article distributed under the terms and conditions of the Creative Commons Attribution license (http://creativecommons.org/licenses/by/3.0/). 